ARTICLE

\title{
Resilience to dealing with COVID-19: university perspective in a low-income health Brazilian region
}

\author{
Bruno Bastos Godoi a \\ Delba Fonseca Santos ${ }^{b}$
}

\section{Abstract}

The COVID-19 pandemic draws into focus the need to rebuild resilient health systems with increased access to quality health services. Reaction ability to changing demand is crucial. Resilience is relevant because all countries have vulnerable communities. One could push the argument further, using as an example the resilience particularly present on the agenda of meetings of the World Health Organization. More critical than ever, it is to take stock of the lessons learned. The stakeholders need to work together to accelerate progress towards universal access to essential health information through resilience. Regarding major societal challenges, which have a local dimension, universities have a key role to play in the knowledge creation of innovative products and services. The need for timely, accurate, and reliable data about the Vale do Jequitinhonha in the health system is unarguably overdue for a real-time, technology-driven, surveillance and reporting infrastructure to respond effectively to public health emergencies. Health system resilience is one of the focuses in low-income region framework and it is an indispensable university strategy for managing the health risks of older adults, and chronic disease patients. COVID-19 can cause disruption in health systems. Disruptions to health service infrastructure can result in loss of life, negative economic impact, and harm to communities. Focused actions include investing in Primary Health Care (PHC) and this encompasses basic preventive, promotive, and curative health cares for enhancing the health status of the people by reducing morbidity and mortality rates. Given the key role of such information for health, the university located in a low-income health region has a fundamental role. The reflections and shreds of evidence showed during

\footnotetext{
a Universidade Federal dos Vales do Jequitinhonha e Mucuri, Diamantina, MG, Brasil.

b Universidade Federal dos Vales do Jequitinhonha e Mucuri, Diamantina, MG, Brasil.
} 
this essay can serve as a framework for health policies in post-pandemic reality and university acting in the population.

Keywords: Resilience. COVID-19. Medical Education. Education Higher. Primary Health Care.

\section{Introduction}

Changes induced by Coronavirus 2019 (COVID-19) were very rapid in people's lives, causing tremendous human suffering and challenging the most basic foundations of societal well-being (OECD, 2020a).

Even though COVID-19 is a viral disease, a variety of non-biological factors, particularly the social determinants of health $(\mathrm{SDH})$, can affect the well-being of individuals in a community. Subjective well-being is defined as a person's cognitive and affective evaluations of his or her life (DIENER; BISWAS-DIENER, 2002). World Health Statistics 2020 sheds light on the progress towards relevant related Sustainable Development Goals (SDG). The COVID-19 pandemic draws into focus the need to rebuild resilient health systems with increased access to quality health services (WHO, 2020a).

Should stir up the benefits and investments return to an alternative approach that targets social factors, addressing the SDH requires collaboration within and across sectors. The new approaches among health and SDH must be reconsidered, with an emphasis on health and well-being in addition to conventional metrics such as Gross Domestic Product (GDP) growth (ANDERSON; MOSSIALOS, 2019).

COVID-19 is a pandemic that led to a crisis with considerable losses of health but also of much of the economy, with high social costs. It has reminded us bluntly of the fragility of some of our most basic human-made systems (OECD, 2020b). Integrating social context will require partnering with disadvantaged patients and communities to better understand the challenges they face (BOOZARY; LAUPACIS, 2020).

Reaction ability to changing demand is crucial. Resilience is relevant because all countries have vulnerable communities. One could push the argument further, using as an example the resilience particularly present on the agenda of meetings of the World Health Organization (WHO) (WHO, 2017a). The concept of resilience means: "the ability of a system, community or society exposed to hazards to resist, absorb, accommodate to and recover from the effects of a hazard in a 
timely and efficient manner, including through the preservation and restoration of its essential basic structures and functions" (UNISDR, 2010).

More critical than ever, it is to take stock of the lessons learned. The stakeholders need to work together to accelerate progress towards universal access to essential health information through resilience (WHO, 2017a). Royston, Pakenham-Walsh and Zielinski (2020) denominate essential health information as the information that people need to protect their health and the health of those for whom they are responsible. It includes information and knowledge to promote health and to prevent, diagnose, and manage disease and injury (ROYSTON; PAKENHAMWALSH; ZIELINSKI, 2020). The coronavirus pandemic is a reminder of the importance of primary care. It's critical to limit the spread of the virus by treating comorbidities that can make COVID-19 so deadly and helping people navigate through the social and psychological challenges of social distancing (PHILLIPS; SULLIVAN; MAYO-SMITH, 2020).

The radical uncertainty nevertheless should not stop us from learning lessons of the past to prepare a systemic response for the future (HYNES et al., 2020). Stakeholder engagement usually involves communicating with stakeholders about achievements. Effective use of communication and technology by health care and public health professionals can bring about an age of the patient and public-centered health information and services (WHO, 2019a).

Regarding major societal challenges, which have a local dimension, universities have a key role to play in the knowledge creation of innovative products and services. Several mechanisms are available to facilitate this resilience process; activities can also be supported by cohesion policy, although may vary among regions according to the priorities.

The need for timely, accurate, and reliable data about the Vale Jequitinhonha in the health system is unarguably overdue for a real-time, technology-driven, surveillance, and reporting infrastructure to respond effectively to public health emergencies. The Jequitinhonha Valley is a region with more than 950,000 citizens in the state of Minas Gerais (Brazilian southeast region), of which two-thirds live in the countryside. This territory is divided into two: High and Middle/Low Jequitinhonha, which have 24 and 35 municipalities respectively and accounted for only $1.3 \%$ of the GDP per capita of Minas Gerais. The rate of poverty and extreme poverty in both territories, despite having reduced significantly in 2000, is still well above the state average. In 2010, the proportion of poor people was 29.7\% in High and 33.3\% in Middle/Low Jequitinhonha (GUIMARÃES, 2017). 
Moreover, the Jequitinhonha Valley counts with one of the biggest Universities (Federal University of Jequitinhonha's Valley and Mucuri) with a countrywide coverage, with plenty of undergraduate courses in the following areas: health, humanities, agrarian, science, and technology, among others.

The purpose of this essay is to discuss the importance of the university to strengthen the individual, community, and health system through resilience in face of changes with COVID-19 in Jequitinhonha Valley, Minas Gerais, Brazil.

\section{Health system resilience: COVID-19 and its implications for the low-income region framework}

The Health system consists of "all organizations, people, and actions whose primary intent is to promote, restore or maintain health" (WHO, 2007). WHO describes health systems in terms of six "building blocks": (a) service delivery, (b) health workforce, (c) health information systems, (d) access to essential medicines, (e) financing, and (f) leadership/governance (WHO, 2007). These functions are vulnerable to shocks and changes. Underdeveloped infrastructure is one of the leading causes of the inability of the population to access basic services. The burden of underdeveloped and non-inclusive infrastructure falls disproportionately on vulnerable and marginalized groups. Phillips et al. (2020) report perhaps it is time to study interventions more focused on their content, target population, and desired outcomes (PHILLIPS; SULLIVAN; MAYO-SMITH, 2020). A good example is a recent literature on primary care programs specifically focused on reducing readmissions (SALUJA et al., 2019; WHITE et al., 2014). Results of the Dargin and Mostafavi (2020) show insights into understanding the role of infrastructure resilience in well-being and highlights why it is so important to use approaches that consider various factors, and evidence of the inequalities in impacts across various sub-populations (DARGIN; MOSTAFAVI, 2020).

Resilience within health systems remains in the discussion, as underscored at the 4th Global Symposium on Health Systems Research, 2016: it is a multidisciplinary context and must be dynamic enough to reflect the complexity and change in diverse health systems (HALDANE et al., 2017). Kruk et al. (2015) describe the process of learning about the Ebola epidemic and have illustrated that several preconditions for resilience were lacking. Resilience has strong external connections to regional and global partners and should not be seen as an apolitical outcome (TOPP, 2020).

Health system resilience is one of the focuses in the low-income region framework and it is an indispensable university strategy for managing the health risks of older adults, and chronic disease patients. COVID-19 can cause disruption in health 
systems. Further, it has conspicuous effects on socio-economic development, particularly in low-income countries (HOPMAN; ALLEGRANZI; MEHTAR, 2020). Infrastructure development and service delivery is a critical public policy and investment area in many developing low-income regions. The influence of community factors on health by various factors such the socioeconomic characteristics, preparedness, and access to resources (Figure 1).

Figure 1 - Infrastructure Resilience Strategy in the low-income region (2020)

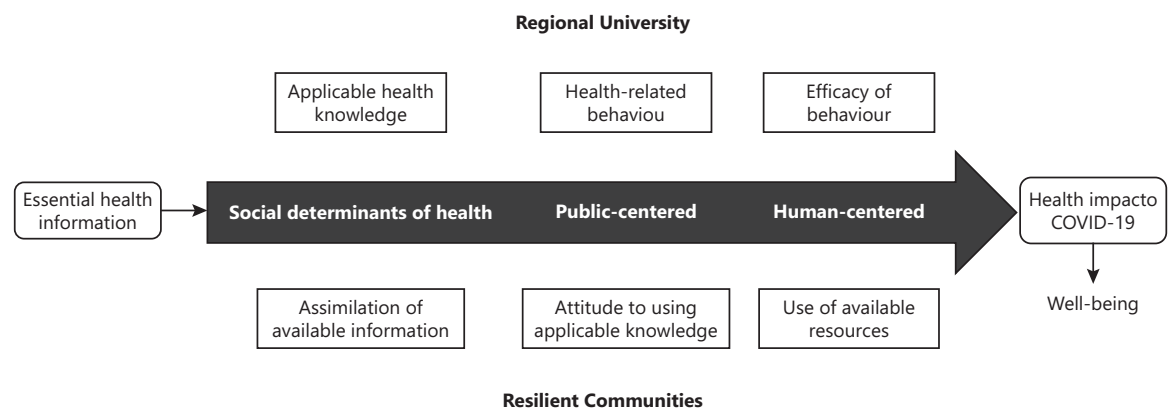

Soure: Authors' elaboration (2020).

Disruptions to health service infrastructure can result in loss of life, negative economic impact, and harm to communities. Roberton et al. (2020) argued that the COVID-19 pandemic will increase mortality due to the virus. It is also likely to increase mortality indirectly if routine health care is disrupted and even the access to health services (as a result of unavoidable shocks, health system collapse, or intentional choices made in responding to the pandemic).

Focused actions include investing in Primary Health Care (PHC), which encompasses basic preventive, promotive, and curative health cares for enhancing the health status of the people by reducing morbidity and mortality rates. Therefore, it is necessary to consider that PHC in the 21st century includes the aim that "people have access to the knowledge, skills, and resources needed to care for themselves and their loved ones" (WHO, 2020b). Approximately 2.1 billion people lack access to safe drinking water and 4.5 billion lack access to sanitation, while 975 million people do not have access to electricity, and 1 billion lack access to all-weather roads globally (WHO, 2017b). Also, where there have been investments to improve primary care, access increased disproportionately.

Preparing cities to reduce risks and strengthening resilience is crucial to ensuring sustainable development and poverty reduction. Yet, pandemic risks increase 
when general community health and well-being weaken. Boozary and Laupacis (2020) describe that poverty is associated with many health risks tied to social context such as housing insecurity, psychological and social isolation, unhealthy food options, trauma, injury, and substance use disorders.

As an example, New Zealand has combined wellbeing measurement to budget allocation and priority setting, which includes health, environment, cultural identity, social connections, and subjective wellbeing (ANDERSON; MOSSIALOS, 2019).

\section{Resilience of primary care of the Jequitinhonha Valley: contribution of the university}

Given the key role of such information for health, the university located in a low-income health region has a fundamental role. In regional communities where there is one university, all these stakeholders stand to gain. Regarding major societal challenges, universities have a key role to play in knowledge creation and its translation into innovative products.

Consequently, it is important to recognize information and communications technologies that bring on new opportunities and challenges for the achievement of the university. New digital technologies and services open new ways of interacting with individuals, citizens, families, communities, patients, and health care workers (Figure 2). However, many countries still require institutional support for the development and consolidation of national eHealth and/or digital health strategies and the implementation of their action plans, which usually require more resources and capabilities (WHO, 2019b).

Figure 2 - Connecting the university and regional communities: a practice of resilience in a person's health pathway (2020).

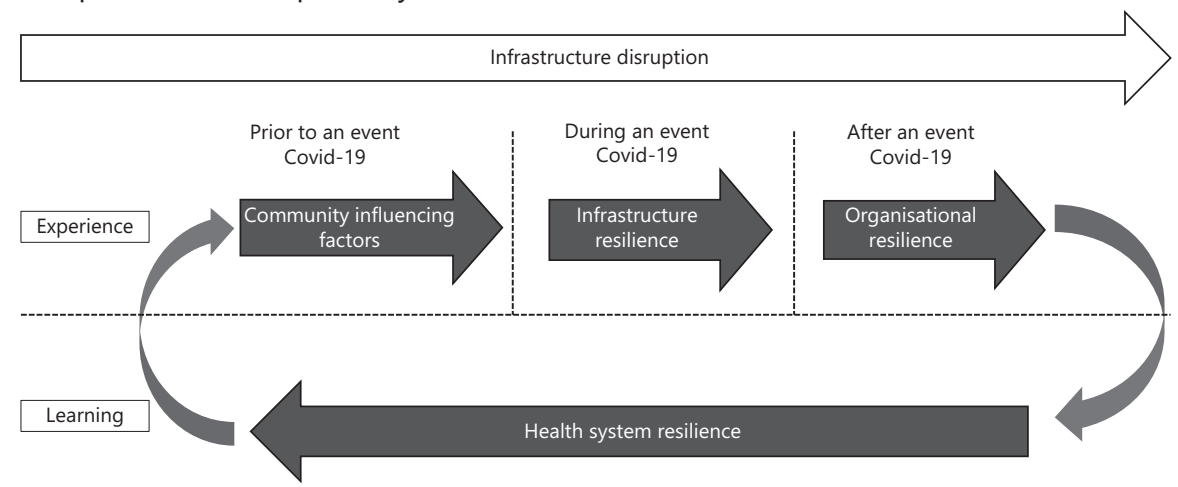

Soure: Authors' elaboration (2020). 
According to the Regionalization Master Plan (PDR) - Unique Health System (SUS - Sistema Único de Saúde), the Jequitinhonha Valley is one of the 14 health macro-regions in the state of Minas Gerais. In particular, this territory represents $14 \%$ of the state, and two-thirds live in the countryside. The micro-region of health constitutes the territorial basis for planning secondary health care and must have the capacity to offer outpatient and hospital services (Figure 3).

Figure 3 - Map of macro-regions according to the PDR-SUS, Minas Gerais, 2020

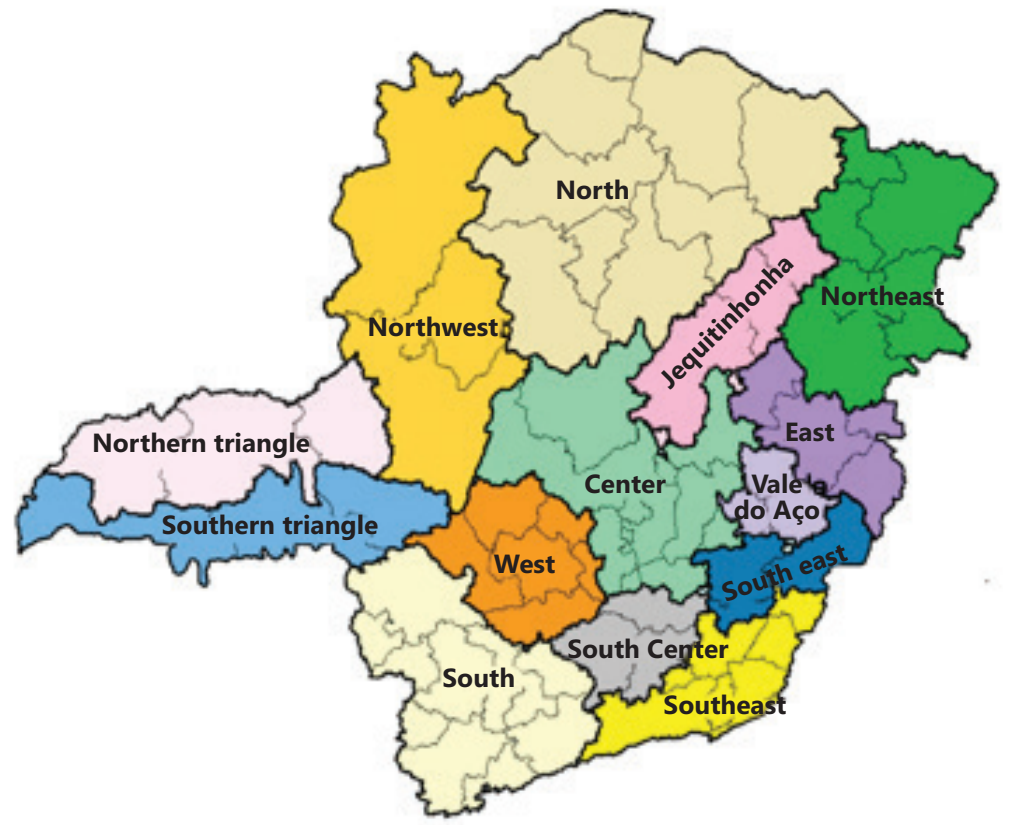

Source: Tabwin/Directorate of Regionalization and Assistance Studies - DREA) (MINAS GERAIS, 2019)

In the Jequitinhonha Valley, more than $70 \%$ of people over 25 years of age did not even have completed elementary school. This is higher than verified for Minas Gerais, which was 54.6\%. Even among the youngest population, 18 to 24 years old, there is a high percentage of people with no Education or with incomplete elementary school, higher for the Middle/Low Jequitinhonha (FUNDAÇÃO JOÃO PINHEIRO, 2017). To cope with such difficulties, the current healthcare delivery models in the low-income region need to be shifted towards primary care models. It is possible to observe that some municipalities, 
especially those belonging to the micro-territories, have PHC coverage between $75 \%$ and $90 \%$ (FUNDAÇÃO JOÃO PINHEIRO, 2017). The social determinants of health and health Education should be incorporated as essential aspects of $\mathrm{PHC}$, in this region.

In light of these concerns, there are reasons to believe that enhancing PHC in this pandemic moment can be a potent alternative. In the Vale of Jequitinhonha, Family Health Strategy is the preferred method of providing PHC. This strategy is a community-based approach where health teams consist of a physician (general practitioner or family health specialist), nurse, nurse technician, and community health workers (CHW). PHC team is responsible for 2,000-3,500 people, with each CHW responsible for up to 750 people (BRASIL, 2017).

There is no doubt that poverty in the Jequitinhonha Valley is of structural nature. In 2014, half of the municipalities still had proportions of these hospitalizations above $30 \%$ (FUNDAÇÃO JOÃO PINHEIRO, 2017). It is necessary to recognize that, despite all the advances achieved, there is still a social gap abyssal, which requires extensive State intervention. The essay in Facchini, Tomasi and Dilélio (2018) brings together advances, problems, and proposals on the quality of PHC in Brazil, and proposes the universalization of primary care with guarantees of investments in the structure of the services (FACCHINI; TOMASI; DILÉLIO, 2018 ). The PHC with a resolution rate of around $85 \%$ of the population's basic health needs reducing $45 \%$ of hospitalizations for conditions sensitive to this level of care (PINTO; GIOVANELLA, 2018).

Jequitinhonha Valley faces health inequality challenges since not all municipalities have access to primary care physicians. In terms of involvement in the public, the university allocated at Jequitinhonha Valley counts on with the Mais Médicos Program collaborating with the faculty of medicine, whose aim is to provide a medical assessment to the population in rural areas and with poor health quality. Adding this, this program promotes the insertion of medical students into the communities to enhance the health quality assessment and also improve medical Education about Primary Health Care, prevention of diseases, and promotion of health (GODOI et al., 2018; GODOI; LEITE, 2020). Therefore, these abilities developed can contribute to the control of the COVID-19 pandemic by disseminating knowledge about symptoms and prevention in furthest areas with low socioeconomic conditions. Seen this, the Brazilian Ministry of Health prioritizes cities with $20 \%$ of its population in extreme poverty, with low and very low HDI located in the Vale Jequitinhonha. The Mais Médicos Program addressed the shortage of doctors in deprived regions and reduced hospitalizations 
for ambulatory care sensitive conditions, and their costs, allowing the Brazilian government to save at least BRL 27.88 (US\$ 6.9 million) between 2014 and 2017 (MAFFIOLI et al., 2019).

In the face of COVID-19 service, health is focused on the hospital network, and PHC has been overlooked. It is necessary to strengthen a plan to combat the COVID-19 epidemic in Brazil, with investment to strengthen this component of the health system. The system can no longer overlook the serious disparities that exist even when there are no direct financial barriers to access. These low levels of structural adequacy in $\mathrm{PHC}$ pose a fundamental challenge for population health and contribute to an increased burden of avoidable diseases and their complications (LISBOA et al., 2020). Even in a pandemic, patients with chronic conditions need ongoing care.

Besides, it is important to mention that the university can change the reality of families and, mainly, health evaluation, among other benefits, such as disseminating knowledge and innovation, integrating Teaching, research, and extension as drivers of regional and national development (GODOI et al., 2020; GODOI; LEITE, 2020; SANTOS et al., 2018). So, at times like the one we are living in now, facing a pandemic full of fears, uncertainty, and anxiety, the university can release all these concerns, or at least help to deal with them, bringing some quality scientific information to contribute to prevention of COVID-19, early assessment of these symptomatic patients, helping them cope with the disease when infected.

Undoubtedly, COVID-19 has changed lives worldwide, both in terms of health and socioeconomically, and has showed the weakness of our health system and where we should improve it (FERREL; RYAN, 2020; OLIVEIRA; GOMES; BARCELLOS, 2020). Likewise, universities, as well as other social fields, suffered from this pandemic and had to reinvent the way Education is passed and how this scientific knowledge can assess the population without support or even evaluate quality information. Notably, the university plays an important role in the community, disseminating reliable scientific information, and also improving the quality of life with scientific and extension programs. Therefore, perhaps this is the main principle of universities, to disseminate knowledge beyond the walls of universities to improve the evaluation of community health, especially during the COVID-19 pandemic. Also, to improve Primary Health Care, the gateway to the evaluation of the health community, to promote health and prevent diseases, such as Sars-Cov2 or even other problems that can plague the community, such as chronic diseases. 
This paper analyzed the opportunity field of the expansion of a university that affects Jequitinhonha Valley innovation in the face of the pandemic. Therefore, UFVJM is the result of a public Education policy that internalized courses to articulate regional development and knowledge production. Creation of the university increased innovation activity, especially in this region, one of the poorest in the country, in the following aspects:

First, through a partnership with the Government of Minas Gerais, the Ezequiel Dias Foundation enabled UFVJM to diagnose COVID-19 to favor decision-making and effective monitoring of the virus circulation in the Jequitinhonha Valley.

Second, the Pro-dean of extension and culture selected COVID-19's Coping Courses free of charge in short distance (online) modality, and also, extension actions such as: Prevention of coronavirus in rural areas through the Coutense Family Agriculture Support Program, in partnership with the Farms and Agricultural Production Division.; tools of science in the quick and accurate diagnosis of COVID-19; Sempre Viva Project: What you need to know about Covid-19; UFVJM in the fight against COVID-19; and Fake news and COVID-19: Interdisciplinary approach to life cycles in health care levels. It is an institutional space for coordination and articulation of actions that contribute to the Teaching-Research-Extension triad.

Third, an early expansion was driven by the desire to increase the proportion of the population receiving tertiary Education. The expansion of the university coincided with the increase in the activity of health care and services and actions of primary health care (eg. Internship for the faculty of medicine students). Besides, the university has other capabilities, for example, accumulated skills or knowledge that can be applied with the creation of news about COVID-19, and in Education (e.g. Undergraduate and graduate courses.) On the Diamantina campus, the university has six Academic Units, especially the Interdisciplinary Faculty in Humanities with a background in Tourism and undergraduate degrees in Portuguese/English, Portuguese/ Spanish Letters, Geography, History or Pedagogy. The Dean of Research and Graduate Studies supports professional master's courses, such as the Graduate Program in Education and Health. The clearest effect was an increase in the general Education level of the labor force.

Finally, the regional collaboration networks considering the role of the university allow us to identify the direct influence on innovation activity. In 2013, the More Doctors Project of the Jequitinhonha Valley was instituted, whose aim was to 
allocate physicians to regions suffering from care voids and to address lack of access to quality health actions and services, strengthening the policy of ongoing Education by integrating Teaching activities and health services.

\section{Conclusions}

The reflections and pieces of evidence showed during this essay can serve as a framework for health policies in post-pandemic reality and related university actions in the population. It is notable the importance of health students at Primary Health Care to improve the assessment of patients with respiratory symptoms to early identify a possibility of COVID-19 among other issues related to primary health. The resilience of university action in PHC, during and post-COVID-19 pandemic, remains an important virtue to enhance the quality of Family Health Strategy and also the university Education directly into the practice of health courses. 


\section{Resiliência ao lidar com a COVID-19: perspectiva universitária em uma região brasileira de saúde de baixa renda}

Resumo

A pandemia da COVID-19 destaca a necessidade de reconstruir sistemas de saúde resilientes com maior acesso a serviços de saúde de qualidade. A capacidade de reação para alterar a demanda é crucial. A resiliência é relevante porque todos os países têm comunidades vulneráveis. Poder-se-ia aprofundar o argumento, usando como exemplo a resiliência particularmente presente na agenda de reuniões da Organização Mundial da Saúde. Mais necessário do que nunca, é fazer um balanço das lições aprendidas. As partes interessadas precisam trabalhar juntas para acelerar o progresso em direção ao acesso universal a informações essenciais de saúde por meio da flexibilidade. Em relação aos grandes desafios societais, que têm uma dimensão local, as universidades têm um papel fundamental a desempenhar na criação de conhecimento de produtos e serviços inovadores. A necessidade de dados oportunos, precisos e confiáveis sobre o Vale do Jequitinhonha no sistema de saúde é indiscutivelmente vencida por uma infraestrutura de vigilância e de relatórios em tempo real, orientada por tecnologia, para responder de maneira eficaz a emergências de saúde pública. A resiliência do sistema de saúde é um dos focos na estrutura da região de baixa renda e é uma estratégia universitária indispensável para gerenciar os riscos à saúde de idosos e de pacientes com doenças crônicas. A COVID-19 pode causar perturbações nos sistemas de saúde. Interrupções na infraestrutura de serviços de saúde podem resultar em perda de vidas, impacto econômico negativo e danos às comunidades. Ações focadas incluem o investimento na Atenção Primária à Saúde (APS), que abrange cuidados básicos de saúde preventivos, promotores e curativos para melhorar o estado de saúde das pessoas, reduzindo as taxas de morbimortalidade. Dado o papel fundamental de tais informações para a saúde, a universidade localizada em uma região de saúde de baixa renda tem um papel fundamental. As reflexões e os fragmentos de evidência mostrados durante este ensaio podem servir de marco para as políticas de saúde na realidade pós-pandêmica e na atuação da universidade na população.

Palavras-chave: Resiliência. COVID-19. Educação Médica. Educação Superior. Atenção Primária à Saúde.

\section{Resiliencia para lidiar con COVID-19: perspectiva universitaria en una región brasileña de salud de bajos ingresos}

\section{Resumen}

La pandemia de COVID-19 enfatiza la necesidad de reconstruir sistemas de salud resilientes con un mayor acceso a servicios de salud de calidad. La capacidad de reacción 
ante la demanda cambiante es crucial. La resiliencia es relevante porque todos los países tienen comunidades vulnerables. Se podría impulsar aún más el argumento, utilizando como ejemplo la resistencia particularmente presente en la agenda de las reuniones de la Organización Mundial de la Salud. Más importante que nunca es hacer un balance de las lecciones aprendidas. Las partes interesadas deben trabajar juntas para acelerar el progreso hacia el acceso universal a la información de salud esencial a través de la resiliencia. Con respecto a los principales desafios sociales, que tienen una dimensión local, las universidades tienen un papel clave a desempeñar en la creación de conocimiento de productos y servicios innovadores. La necesidad de datos oportunos, precisos y confiables sobre el Vale do Jequitinhonha en el sistema de salud es indudablemente atrasada por una infraestructura de vigilancia e informes en tiempo real, impulsada por la tecnología, para responder de manera efectiva a las emergencias de salud pública. La resiliencia del sistema de salud es uno de los enfoques en el marco de una región de bajos ingresos y es una estrategia universitaria indispensable para gestionar los riesgos de salud de los adultos mayores y los pacientes con enfermedades crónicas. El COVID-19 puede causar interrupción en los sistemas de salud. Las interrupciones en la infraestructura de los servicios de salud pueden provocar la pérdida de vidas, un impacto económico negativo y daños a las comunidades. Las acciones enfocadas incluyen la inversión en Atención Primaria de Salud (APS) que abarca cuidados básicos de salud de prevención, promoción y curación para mejorar el estado de salud de las personas al reducir las tasas de morbilidad y mortalidad. Dado el papel clave de dicha información para la salud, la universidad ubicada en una región de salud de bajos ingresos tiene un papel fundamental. Las reflexiones y fragmentos de evidencia mostrados durante este ensayo pueden servir como marco para las políticas de salud en la realidad pospandémica y la actuación universitaria en la población.

Palabras clave: Resiliencia. COVID-19. Educación Médica. Educación Superior. Primeros Auxilios. 


\section{References}

ANDERSON, M.; MOSSIALOS, E. Beyond gross domestic product for New Zealand's wellbeing budget. Lancet, London, v. 4, n. 7, E320-E321, jul. 2019 jul. 2019. https://doi.org/10.1016/S2468-2667(19)30109-4

BOOZARY, A.; LAUPACIS, A. The mirage of universality: Canada's failure to act on social policy and health care. CMAJ, Montreal, v. 192, n. 5, E105-E106, feb. 2020. https://doi.org/10.1503/cmaj.200085

BRASIL. Portaria $\mathrm{n}^{\mathrm{o}} 2.436$, de 21 de setembro de 2017. Aprova a Política Nacional de Atenção Básica, estabelecendo a revisão de diretrizes para a organização da Atenção Básica, no âmbito do Sistema Único de Saúde (SUS). Diário Oficial da União, Brasília, DF, 22 set. 2017.

DARGIN, J. S.; MOSTAFAVI, A. Human-centric infrastructure resilience: Uncovering well-being risk disparity due to infrastructure disruptions in disasters. PloS ONE, [s. 1.], v. 15, n. 6, e0234381, jun. 2020. https://doi.org/10.1371/journal.pone.0234381

DIENER, E.; BISWAS-DIENER, R. Will money increase subjective well-being? A literature review and guide to needed research. Social Indicators Research, Dordrecht, v. 57, n. 2, p. 119-169, feb. 2002. https://doi.org/10.1007/978-90-481-2350-6_6

FACCHINI, L. A.; TOMASI, E.; DILÉLIO, A. S. Quality of primary health care in Brazil: advances, challenges and perspectives. Saúde em Debate, v. 42, n spe.1, p. 208-222, Sep. 2018. https://doi.org/10.1590/0103-11042018s114

FERREL, M. N.; RYAN, J. J. The Impact of COVID-19 on Medical Education. Cureus, Palo Alto, v. 12, n. 3, e7492, Mar. 2020. https://doi.org/10.7759/cureus.7492

FUNDAÇÃO JOÃO PINHEIRO. Plano de desenvolvimento para o Jequitinhonha Valley: educação, saúde, assistência social, cultura e segurança pública. Belo Horizonte, 2017.

GODOI, B. B. et al. Assessing palliative care knowledge in a public health hospital. MOJ Gerontology \& Geriatrics, [s. 1.], v. 5, n. 1, p. 32-35, 2020.

GODOI, B. B. et al. Capacitação de Agentes Comunitários de Saúde no Município de Diamantina -MG. Revista Ciência em Extensão, Botucatu, v. 14, n. 1, p. 54-69, 2018. 
GODOI, B. B.; LEITE, L. F. A. Educação permanente em agentes comunitários de saúde: experiência de um projeto de intervenção. Extensio: Revista Eletrônica de Extensão, Florianópolis, v. 17, n. 35, p. 138-146, 2020. https://doi.org/10.5007/1807-0221.2020v17n35p138

GUIMARÃES, A. Q. Plano de Desenvolvimento do Jequitinhonha Valley: direções prioritárias para o desenvolvimento da região. Belo Horizonte: [s. n.], 2017.

HALDANE, V. et al. Health systems resilience: meaningful construct or catchphrase? Lancet, London, v. 389, n. 10078, p. 1513, Apr. 2017. https://doi.org/10.1016/S0140-6736(17)30946-7

HOPMAN, J.; ALLEGRANZI, B.; MEHTAR, S. Managing COVID-19 in low- and middle-income countries. Journal of the American Medical Association, Chicago, v. 323, n. 16, p. 1549-1550, Apr. 2020. https://doi.org/10.1001/jama.2020.4169

HYNES, W. et al. Bouncing forward: a resilience approach to dealing with COVID-19 and future systemic shocks. Environment Systems and Decisions, New York, v. 40, n. 2, p. 174-184, May 2020. https://doi.org/10.1007/s10669-020-09776-x

KRUK, M. E. et al. What is a resilient health system? Lessons from Ebola. Lancet, London, v. 385, n. 9980, p. 1910-1912, May 2015. https://doi.org/10.1016/S0140-6736(15)60755-3

LISBOA, L. A. S. et al. Characteristics of primary care and rates of pediatric hospitalizations in Brazil. Revista de Saúde Pública, São Paulo, v. 54, n. 32, p. 1-13, Mar 2020. https://doi.org/10.11606/s1518-8787.2020054001784

MAFFIOLI, E. M. et al. Addressing inequalities in medical workforce distribution: Evidence from a quasi-experimental study in Brazil. BMJ Global Health, [London], v. 4, n. 6, p. 1827, Nov. 2019. https://doi.org/10.1136/bmjgh-2019-001827

MINAS GERAIS. Secretaria de Estado da Saúde. Plano diretor de regionalização da saúde de Minas Gerais (PDR/MG). Belo Horizonte, 2020.

ORGANIZATION FOR ECONOMIC COOPERATION AND DEVELOPMENT - OECD. A systemic resilience approach to dealing with Covid-19 and future shocks. OECD. Paris, 2020b. 


\section{ORGANIZATION FOR ECONOMIC COOPERATION AND}

DEVELOPMENT - OECD. COVID-19: protecting people and societies. Paris, 2020a.

OLIVEIRA, J. B. A.; GOMES, M.; BARCELLOS, T. A Covid-19 e a volta às aulas: ouvindo as evidências. Ensaio: Avaliação e Políticas Públicas em Educação, Rio de Janeiro, v. 28, n. 108, p. 555-578, jul./set. 2020. https://doi.org/10.1590/s0104-40362020002802885

PHILLIPS, R. S.; SULLIVAN, E. E.; MAYO-SMITH, M. F. The patient-centered medical home and the challenge of evaluating complex interventions. JAMA Network Open, v. 3, n. 2, e1920827, 2020. https://doi.org/10.1001/jamanetworkopen.2019.20827

PINTO, L. F.; GIOVANELLA, L. The family health strategy: expanding access and reducing hospitalizations due to ambulatory care sensitive conditions (ACSC). Ciência \& Saúde Coletiva, Rio de Janeiro, v. 23, n. 6, p. 1903-1913, jun. 2018. https://doi.org/10.1590/1413-81232018236.05592018

ROBERTON, T. et al. Early estimates of the indirect effects of the COVID-19 pandemic on maternal and child mortality in low-income and middle-income countries: a modelling study. The Lancet Global Health, London, v. 8, n. 7, e901-e908, Jul. 2020. https://doi.org/10.1016/S2214-109X(20)30229-1

ROYSTON, G.; PAKENHAM-WALSH, N.; ZIELINSKI, C. Universal access to essential health information: accelerating progress towards universal health coverage and other SDG health targets. BMJ Global Health, London, v. 5, n. 5, e002475, 2020. https://doi.org/10.1136/bmjgh-2020-002475

SALUJA, S. et al. Primary care: the new frontier for reducing readmissions. Journal of General Internal Medicine, Philadelphia, v. 34, n. 12, p. 2894-2897, Dec. 2019. https://doi.org/10.1007/s11606-019-05428-2

SANTOS, T. D. B. et al. Mutirão de saúde como ação extensiva e integrativa com a atenção primária. Revista Médica de Minas Gerais, Belo Horizonte, v. 28, e-1979, 2018. https:// doi.org/10.5935/2238-3182.20180013

TOPP, S. M. Power and politics: the case for linking resilience to health system governance. BMJ Global Health, London, v. 5, n. 6, p. e002891, 2020. http://dx.doi.org/10.1136/bmjgh-2020-002891

UN OFFICE FOR DISASTER RISK REDUCTION - UNISDR. Making cities resilient: my city is getting ready, 2010-2011. [S.1], 2010. 
WHITE, B. et al. Reducing hospital readmissions through primary care practice transformation. Journal of Family Practice, New York, v. 63, n. 2, p. 67-73, 2014.

WORLD HEALTH ORGANISATION - WHO. 2.1 billion people lack safe drinking water at home, more than twice as many lack safe sanitation. Geneva, 2017b July 12. Available from: https://www.who.int/news/item/1207-2017-2-1-billion-people-lack-safe-drinking-water-at-home-more-thantwice-as-many-lack-safe-sanitation. Access in: 2020 June 10.

WORLD HEALTH ORGANISATION - WHO. A vision for primary care in the 21st century: towards universal health coverage and the sustainable development goals. Geneva, 2020b. Available from: https://apps.who. int/iris/bitstream/handle/10665/328065/WHO-HIS-SDS-2018.15-eng. pdf? sequence=1\&isAllowed=y. Access in: 2020 June 10 .

WORLD HEALTH ORGANISATION - WHO. Draft global strategy on digital health 2020-2024. Geneva, 2019b. Available from: https://www.who. int/docs/default-source/documents/gs4dh0c510c483aaa42b1834a8f4d27 6c6352.pdf. Access in: 2020 June 10.

WORLD HEALTH ORGANISATION - WHO. Everybody business: strengthening health systems to improve health outcomes: WHO's framework for action. Geneva, 2007. Available from: https://www.who.int/healthsystems/ strategy/everybodys_business.pdf. Access in: 2020 June 10.

WORLD HEALTH ORGANISATION - WHO. Strengthening resilience: a priority shared by Health 2020 and the sustainable development goals. Copenhagen, 2017a. Available from: https://www.euro.who.int/_data/ assets/pdf_file/0005/351284/resilience-report-20171004-h1635.pdf. Access in: 2020 June 10.

\section{WORLD HEALTH ORGANISATION - WHO. WHO Guideline:} recommendations on digital interventions for health system strengthening. Geneva, 2019a. Available from: https://apps.who.int/iris/bitstream/hand le/10665/311941/9789241550505-eng.pdf?ua=1. Access in: 2020 June 10.

WORLD HEALTH ORGANISATION - WHO. World health statistics 2020: monitoring health for the SDGs, sustainable development goals. Geneva, 2020a. Available from: https://apps.who.int/iris/bitstream/hand le $/ 10665 / 332070 / 9789240005105$-eng.pdf? sequence $=1$ \&isAllowed $=y$. Access in: 2020 June 10. 


\section{Information about the authors}

Bruno Bastos Godoi: Physician from the Universidade Federal dos Vales do Jequitinhonha e Mucuri. Contact: bastosgodoi@gmail.com

iD https://orcid.org/0000-0001-7100-8243

Delba Fonseca Santos: PhD in Public Health from the Universidade Estadual de Campinas. Post-doctorate by the Centro de Epidemiologia da Universidade Federal de Pelotas. Associate III, Faculdade de Medicina, Diamantina/MG - Universidade Federal dos Vales do Jequitinhonha e Mucuri. Contact: delbafonseca@yahoo.com.br

iD https://orcid.org/0000-0003-2404-5791 